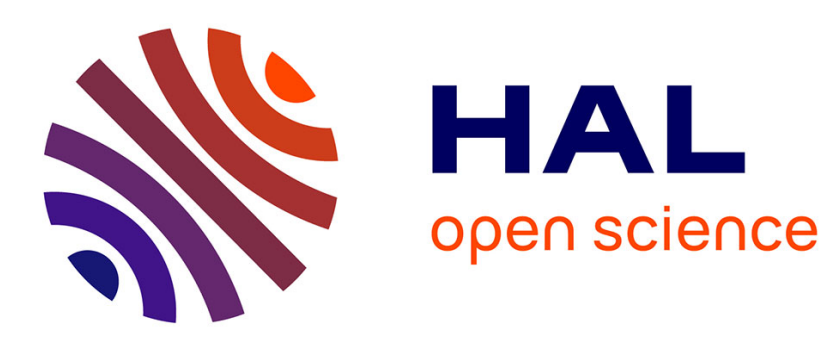

\title{
Influence of nitrogen availability on growth and development of tomato plants until fruit-setting
}

\author{
Y. Dumas, J. Suniaga Quijada, M. Bonafous
}

\section{To cite this version:}

Y. Dumas, J. Suniaga Quijada, M. Bonafous. Influence of nitrogen availability on growth and development of tomato plants until fruit-setting. Optimization of plant nutrition, Kluwer, 1993. hal02851018

\section{HAL Id: hal-02851018 \\ https://hal.inrae.fr/hal-02851018}

Submitted on 7 Jun 2020

HAL is a multi-disciplinary open access archive for the deposit and dissemination of scientific research documents, whether they are published or not. The documents may come from teaching and research institutions in France or abroad, or from public or private research centers.
L'archive ouverte pluridisciplinaire HAL, est destinée au dépôt et à la diffusion de documents scientifiques de niveau recherche, publiés ou non, émanant des établissements d'enseignement et de recherche français ou étrangers, des laboratoires publics ou privés. 


\title{
Influence of nitrogen availability on growth and development of tomato plants until fruit-setting
}

\author{
Y. DUMAS, J. SUNIAGA QUIJADA and M. BONAFOUS \\ National Institute for Agronomic Research, INRA, BP 91, F-84143 Montfavet, France
}

Key words: Lycopersicon esculentum, nitrogen supply, nutrient solution, tomato for processing

\begin{abstract}
The influence of $\mathrm{N}$ availability in the root medium on growth and development of tomato for the processing industry was studied during the period from sowing time until the beginning of fruit-setting. In a growth chamber or in a glasshouse sand pots were regularly rinsed with complete solutions with or without $\mathrm{N}$ before emergence and with $0,2,6$ and $18 \mathrm{meq} \mathrm{N} \mathrm{L}^{-1}$ as ammonium-nitrate after emergence. The presence of $\mathrm{N}$ in the nutrient solution did not affect the germination process and the emergence rate. The absorption of $\mathrm{N}$ began immediately after emergence. When no $\mathrm{N}$ was supplied growth was reduced and ceased totally after 2 weeks. At a higher $\mathrm{N}$ supply shoot and root growth was stimulated and the truss appearance rate and the percentage of the fruits in total dry weight was increased. 6 meq. $\mathrm{N} \mathrm{L}^{-1}$ in the nutrient solution seemed to be the optimal level for young tomato seedlings from emergence to early blooming.
\end{abstract}

\section{Introduction}

Nitrogen absorption by tomato plants has been widely studied. However, in these studies transplants have generally been used during their reproductive phase (Cornillon and Auge, 1980). Such results may be affected by plant traumatism during transplanting. Haag et al. (1978) and Halbrooks and Wilcox (1980) studied the mineral nutrition of tomato seedlings (cultivars used for canning industry) but their research started 21 days after sowing. On the contrary Widders (1989) studied the effect of nitrogen and phosphorus supply on dry matter accumulation in tomato transplants in the nursery from sowing to transplanting only.

Tomatoes for processing are currently sown directly in the field in order to reduce production costs. Once-over mechanical harvesting requires early concentrated ripening and foliage which is not developed. For proper management in the commercial production of tomato crops for the processing industry, a thorough understanding of the nitrogen needs of tomato plants during their total development and especially during crop establishment is essential.

Therefore the influence of $\mathrm{N}$ supply on tomato growth and development has been studied during the whole period between sowing time and the beginning of fruit-setting.

\section{Methods}

Pot experiments were performed in a growth chamber and in a glasshouse. In each case, uniform-sized seeds of a common cultivar for processing industry (UC82 from Petoseed, California) were placed $1 \mathrm{~cm}$ deep in fine inert sand (particle size between 0.8 and $1 \mathrm{~mm}$ ). More than $98 \%$ of the seeds germinated.

\section{Growth chamber experiment}

Plantlets grew in $1.33 \mathrm{~L}$ pots filled with inert sand for up to 18 days. 9 to 560 seeds (of $\sim 3 \mathrm{mg}$ 
each) were sown per pot depending of the intended harvesting date. For the sake of accuracy and in order to provide enough material for chemical analysis, sampling during germination required a greater number of seeds. Plants received light 16 hours per day; the temperature was $18^{\circ} \mathrm{C}$ during the night and $24^{\circ} \mathrm{C}$ during the day and the relative humidity was $70 \%$. The effects of three nutrient solutions were compared, i.e. a complete solution ('N'), a solution without nitrogen (' $O N$ ') and deionized water with added traces of $\mathrm{CaSO}_{4}$ (' 00 '). The solutions were supplied twice a day starting at the date of sowing. Pots could drain freely. There were four replications in a randomized design. Plants were sampled every day until day 10 , and every 2 nd day after that. Four pots per treatment were sampled at each sampling date.

\section{Glasshouse experiment}

Plantlets grew in $10 \mathrm{~L}$ pots filled with inert sand up to the beginning of fruit-setting. The weekly mean values of minimum air temperature were $15-16^{\circ} \mathrm{C}$ and the weekly mean values of maximum air temperature were $30-32^{\circ} \mathrm{C}$. The effects of four nutrient solutions were compared, i.e. a complete solution (' $N$ ') containing all the nutrients and $6 \mathrm{meq} \mathrm{N} \mathrm{L}^{-1}$, a complete solution overdosed in nitrogen ('3N') with 18 meq $\mathrm{N} \mathrm{L}^{-1}$, a complete solution underdosed (' $1 / 3 \mathrm{~N}$ ') with 2 meq $\mathrm{N} \mathrm{L}^{-1}$ and a solution containing all the nutrients except $\mathrm{N}$ (' $\mathrm{ON}$ '). From the time of sowing, the solutions were supplied at least twice a day and pots could drain freely. The design was at random with four replications, i.e. four pots for each treatment and each sampling date $(14,22,33,47$ and 60 days after sowing). After emergence, four plants were kept per pot. A treatment with soil was added (labelled ' $0 \mathrm{Ns}$ ') to estimate its $\mathrm{N}$ supply in comparison to the nutrient solutions. It received the solution ' $0 \mathrm{~N}$ '. It was a clayey calcareous soil, poor in phosphorus but well provided with potassium and mag nesium and with a total nitrogen content of $1.2 \mathrm{~g}$ per $\mathrm{kg}$ of dry soil.

\section{Nutrient solutions}

The basic solutions were derived from Hoagland and Amon (1950). They were considered to be suitable for tomato (Cornillon and Maisonneuve, 1985). For the growth chamber experiments the composition of the complete solution was as follows: $6.5,1.5$ and $1.0 \mathrm{meq} \mathrm{L}^{-1}$ for $\mathrm{NO}_{3}^{-}$, $\mathrm{PO}_{4}^{3-}$, and $\mathrm{SO}_{4}^{2-}$, respectively, and 3.5, 3.0, 1.0, 0.5 , and 1.0 meq L ${ }^{-1}$ for $\mathrm{K}^{+}, \mathrm{Ca}^{2+}, \mathrm{Mg}^{2+}, \mathrm{NH}_{4}^{+}$, and $\mathrm{H}^{+}$, respectively. In the glasshouse experiment the composition of the complete solution (N) was as follows: $3.0,3.0,3.0$, and $2.0 \mathrm{meq}$ $\mathrm{L}^{-1}$ for $\mathrm{NO}_{3}^{-}, \mathrm{PO}_{4}^{3-}, \mathrm{SO}_{4}^{2-}$, and $\mathrm{Cl}^{-}$, respectively, and $3.0,2.0,1.0,3.0$, and $2.0 \mathrm{meq} \mathrm{L}^{-1}$ for $\mathrm{K}^{+}, \mathrm{Ca}^{2+}, \mathrm{Mg}^{2+}, \mathrm{NH}_{4}^{+}$, and $\mathrm{H}^{+}$, respectively. In each experiment micronutrients $(\mathrm{B}, \mathrm{Cl}, \mathrm{Cu}, \mathrm{Fe}$, $\mathrm{Mn}, \mathrm{Mo}, \mathrm{Zn}$ ) were added to the solutions and the $\mathrm{pH}$ was about 5.3.

\section{Observations and measurements}

In growth chamber experiments, germination, emergence, decrease in, seed reserves, shoot height (using plant photocopies) and dry matter distribution in the plantlet were accurately observed and measured.

In glasshouse experiments, dry matter accumulation in the different plant organs was measured on harvested plants. Between destructive plant samplings and in order to better understand its changes with time, estimations of shoot dry matter per plant were performed using regressions with linear measurements of leaf length or truss length (Dumas, 1990) 18, 26 and 40 days after sowing.

Total $\mathrm{N}$ analyses were carried out on the harvested plants using the Kjeldahl method. Ethanol extracts of leaf-blades were analysed by spectrophotometry. The cell ultrastructure of the upper side leaf palisade tissue was studied by transmission electron microscopy.

The results were processed by analysis of variance and means were compared by the Newman-Keuls method.

\section{Results}

Germination, emergence and initial growth (experiment in the growth chamber)

Four days after sowing, germination was finished (98\% radicles appearance) in all the treatments. 
On day $6,80 \%$ and $60 \%$ of the ' $N$ ' and ' $0 \mathrm{~N}$ ' plants had emerged respectively, whereas plants from the ' 00 ' treatment were one day later. From sowing to day 6 the total seed + plantlet dry matter weight (DMW) continuously decreased for all the treatments alike. From day 6 on DMW began to increase for ' $N$ ' and ' $0 \mathrm{~N}$ ' at the same rate until day 8 , while it continued to decrease for '00' (Fig. 1). However, from day 6, shoot height in ' $N$ ' was greater than in '0N' (data not shown). In fact, Figure 2 shows that, on day 6 and later, shoot DMW per plant was significantly increased at the higher $\mathrm{N}$ supply while root DMW was significantly lower for the ' $\mathrm{N}$ ' treatment compared to the ' $0 \mathrm{~N}$ ' and the ' 00 ' treatments. Thus, immediately after emergence root growth partly compensated for the inhibited shoot growth when nitrogen was limiting.

On day 9 , total dry matter weight per plant was significantly different for the treatments ' $\mathrm{N}$ ' and ' $0 \mathrm{~N}$ ', and this characterized the beginning of the global effect of nitrogen on plant DMW (Fig. 1). This difference increased after day 10. As for treatment ' 00 ', total DMW per plant decreased until day 10 and then increased slowly. On day 14, plants of the treatment ' $N$ ' were at the 2 true leaves stage, those of the treatment ' $0 \mathrm{~N}$ ' at the beginning of 1 true leaf stage and

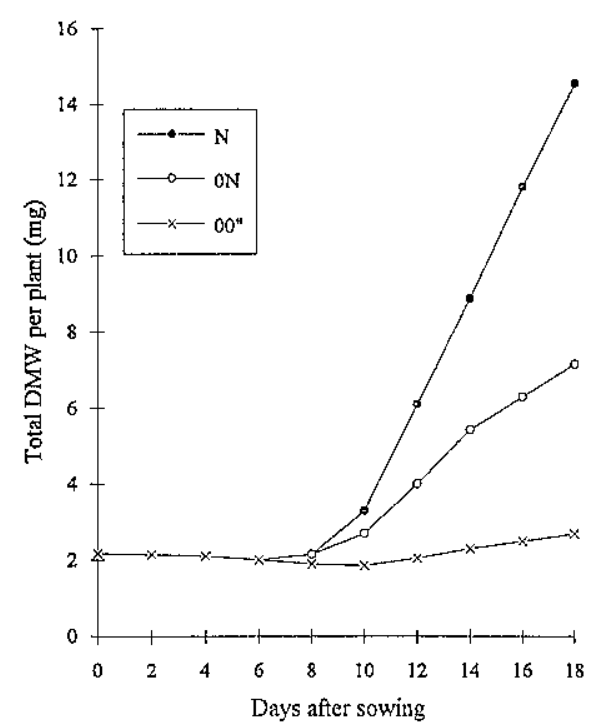

Fig. 1. Dry matter accumulation during the initial growth of tomato seedlings. For a same abscisse value, two points situated on two distinct curves mean that their ordinate values are significantly different $(p=0.05)$.

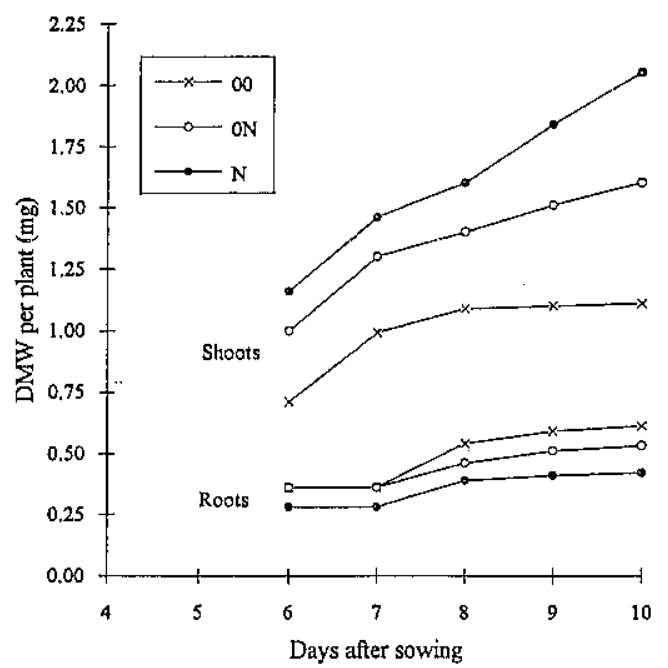

Fig. 2. Changes in shoot and root DMW during initial growth. For a same abscisse value, two points situated on two distinct curves mean that their ordinate values are significantly different $(p=0.05)$.

those of the treatment ' 00 ' at the 2 cotyledon stage.

\section{Plant growth from emergence to fruit-setting (experiment in glasshouse)}

In the treatment ' $0 \mathrm{~N}$ ', plant growth was very slow and stopped 22 days after sowing but plants were still alive on day 60 at a stage of 3-4 small true leaves. Figure 3 shows an increase in the shoot dry matter accumulation rate for the 4 other treatments from day 14 to day 60 after sowing. During the period of strictly vegetative growth (until day 26, appearance of the first truss) treatments ' $N$ ' and ' $3 N$ ' had rather similar growth rates which increased with time. For the treatment ' $1 / 3 \mathrm{~N}$ ', the growth rate was always 3 to 4 times lower. The growth rate of the treatment ' $0 \mathrm{Ns}$ ' was roughly equivalent to the growth rate of ' $3 \mathrm{~N}$ '. This classification of the four treatments globally remained between the 1st truss appearance stage and the 1st truss blooming stage. Changes appeared at day 40 (beginning of blooming) when ' $3 \mathrm{~N}$ ' plants started to grow faster and '0Ns' slower than those of the ' $\mathrm{N}$ ' treatment.

From a general point of view, root growth was quite similar to shoot growth, except for some details. On day 14, ' $1 / 3 \mathrm{~N}$ ' root DMW was significantly higher than ' $3 \mathrm{~N}$ ' DMW and was 

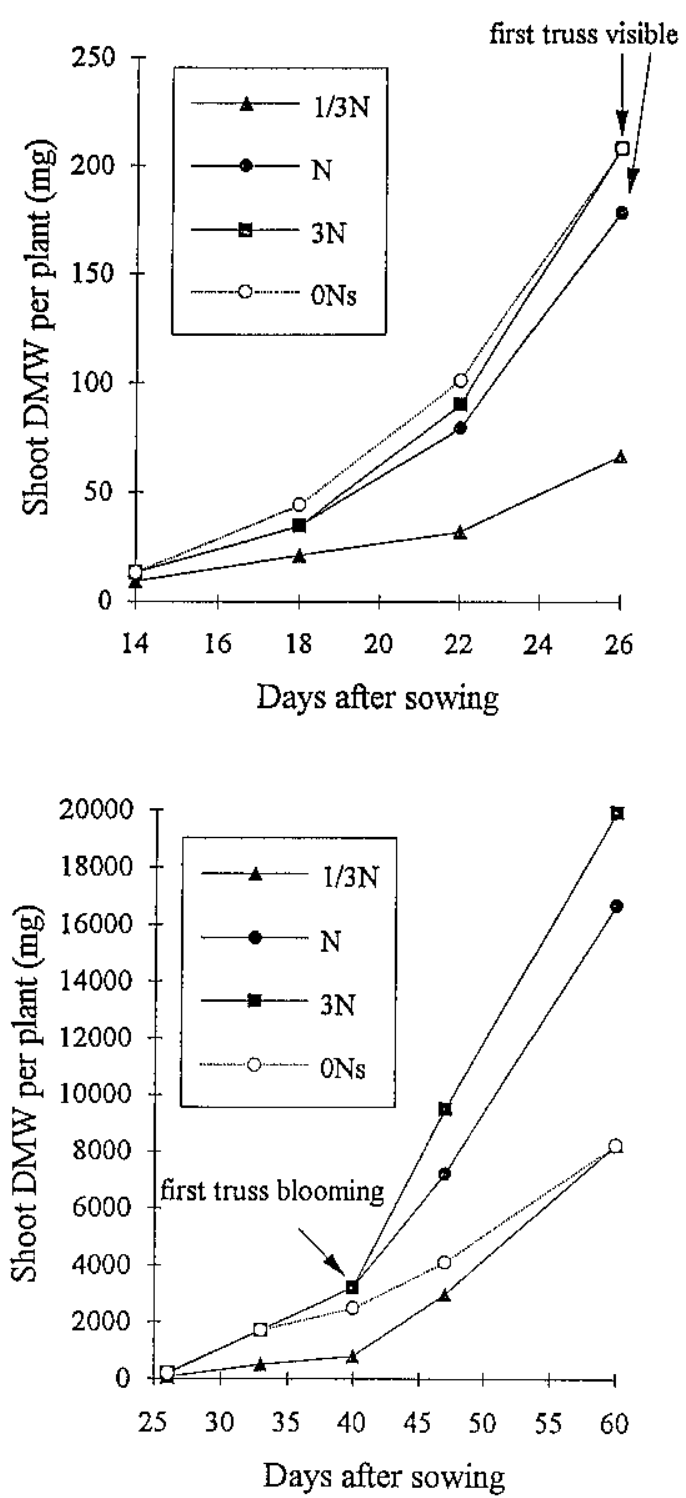

Fig. 3. Shot dry matter accumulation per plant after seedling emergence until fruit-setting. For a same abscisse value, two points situated on two distinct curves mean that their ordinate values are significantly different $(p=0.05)$.

equivalent to that of ' $N$ '. Prior to the blooming stage, ' $\mathrm{N}$ ' root DMW was significantly higher than that of ' $3 \mathrm{~N}$ ' but after day 40 this was reversed (data not presented).

\section{Plant development}

The first truss appeared on some plants for the treatments ' $0 \mathrm{Ns}$ ', ' $\mathrm{N}$ ' and ' $3 \mathrm{~N}$ ' on day 26 but for

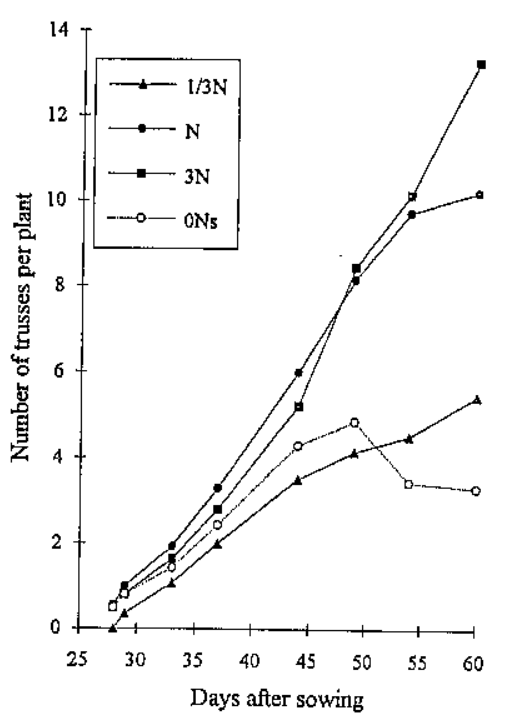

Fig. 4. Changes in cumulative total number of trusses per plant.

' $1 / 3 \mathrm{~N}$ ' on day 29 . Figure 4 shows the progression of the number of trusses per plant. ' $1 / 3 \mathrm{~N}$ ' was delayed and characterized by a lower truss appearance rate. ' $\mathrm{N}$ ' was surpassed by ' $3 \mathrm{~N}$ ' at the beginning of the first fruits swelling, 54 days after sowing. '0Ns' was surpassed by ' $1 / 3 \mathrm{~N}$ ' as soon as blooming occured and during fruit swelling there even was a decrease in the number of trusses (i.e. trusses were aborted). On day 60 , mean truss length was $14.8 \mathrm{~mm}$ for ' $1 / 3 \mathrm{~N}$ ' and ' $0 \mathrm{Ns}$ ', $13.5 \mathrm{~mm}$ for ' $\mathrm{N}$ ' and $11.0 \mathrm{~mm}$ for ' $3 \mathrm{~N}$ ' where many trusses were aborted. Fruit DMW characteristics on day 60 are presented in Table 1. Treatment ' $N$ ' was most efficient in early fruit production.

\section{Aspects of plant metabolism}

Nitrogen accumulation in the plant shoots was approximately related to DM accumulation, ex cept that the treatment ' $3 \mathrm{~N}$ ' led to a much higher $\mathrm{N}$ accumulation than the treatment ' $\mathrm{N}$ ' early on. This was due to a higher $\mathrm{N}$-concentration in the plant (Table 2). When $\mathrm{N}$ was highly available (treatment ' $3 \mathrm{~N}$ ' compared to ' $\mathrm{N}$ '), there was overconsumption and lower efficiency. Nitrogen accumulation in the root system was about one third of that in the shoot in each treatment. 
Table 1. Fruit DMW characteristics in the glasshouse experiment 60 days after sowing

\begin{tabular}{lcc}
\hline $\begin{array}{l}\text { Treat- } \\
\text { ment }\end{array}$ & $\begin{array}{l}\text { Fruit DMW per plant } \\
(\mathrm{mg})\end{array}$ & $\begin{array}{l}\text { Fruit DMW/total DMW } \\
(\%)\end{array}$ \\
\hline $1 / 3 \mathrm{~N}$ & $563 \mathrm{~b}^{*}$ & $8.1 \mathrm{~b}$ \\
$\mathrm{~N}$ & $1857 \mathrm{a}$ & $13.0 \mathrm{a}$ \\
$3 \mathrm{~N}$ & $1012 \mathrm{~b}$ & $5.4 \mathrm{~b}$ \\
$0 \mathrm{Ns}$ & $597 \mathrm{~b}$ & $8.8 \mathrm{~b}$ \\
\hline
\end{tabular}

* the results followed by the same letter are not statistically different (Newman-Keuls method, $p=0.05$ ).

Table 2. Mean nitrogen concentration (\% of DM) in the plant for two treatments

\begin{tabular}{llllll}
\hline Plant & Treatment & \multicolumn{4}{c}{ Number of days after sowing } \\
\cline { 3 - 6 } part & & 14 & 33 & 47 & 60 \\
\hline Shoot & $\mathrm{N}$ & 6.14 & 3.64 & - & - \\
& $3 \mathrm{~N}$ & 8.13 & 7.06 & - & - \\
Leaf - & $\mathrm{N}$ & - & - & 2.78 & 2.75 \\
blade & 3N & - & - & 5.45 & 5.25 \\
\hline
\end{tabular}

Figure 5 represents the pigment absorption spectrum of leaf ethanol extracts. The influence of $\mathrm{N}$ availability on leaf chlorophyll content was demonstrated by the two typical chlorophyll peaks for the wave lengths 434 and $664 \mathrm{~nm}$. Absorbency between 300 and $350 \mathrm{~nm}$ is typical of the presence of polyphenols. Polyphenol content was considerably increased by low $\mathrm{N}$ availability.

Electron microscopy showed that chloroplasts were functional at emergence and had well

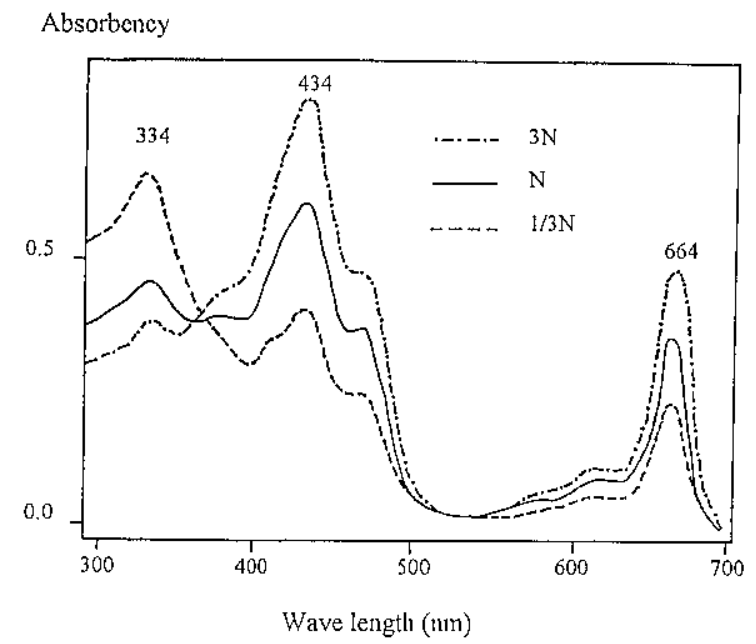

Fig. 5. Absorption spectrum of leaf-blade tomato pigments at the beginning of the blooming stage. structured thylakoids. A few days after emergence, the absence of nitrogen in the nutrient solution resulted in enormous starch accumulation in the chloroplasts of plants sampled at the beginning of the light period. Later, at the reproductive stage, the more available nitrogen was, the less starch there was in the chloroplasts. $\mathrm{N}$ deficiency led to increasing storage of starch which resulted in a deformation of the chloroplasts and a dislocation of the thylakoids.

\section{Discussion}

Until emergence, no nitrogen was taken up by the seedlings. During this phase, the plantlets were completely dependent on seed reserves and therefore not affected by the external $\mathrm{N}$ supply. Catabolism exceeded anabolism, resulting in a DMW decrease. This phenomenon was already described for wheat (Pinto Contreras, 1981), for millet by Siband (1981) and for corn by Bourdu and Gregory (1983). In the same growth chamber experiment as the one described here, Suniaga Quijada (1991) showed that only potassium was absorbed between day 4 and day 6 and that the utilization of seed reserves between day 5 and day 10 was accelerated in the treatments ' $\mathrm{N}$ ' and ' $0 \mathrm{~N}$ ', resulting in quicker emergence and growth. On day $6, \mathrm{~N}$ absorption and assimilation began simultaneously with the onset of photosynthesis. An influence of nitrogen on total DMW could be measured 3 days later i.e. on day 9 when the seed reserves were used up (Suniaga Quijada, 1991). At that time, the higher root DM production in the $\mathrm{N}$-deficient treatments could be explained by a temporary carbohydrate accumulation in the root system as had been suggested by Champigny et al. (1985) for wheat and by Just et al. (1989) for sunflowers. According to these authors, this accumulation should be possible by saving energy as there is little or no nitrate to be reduced and/or by reorienting carbon flux when plants have to face limiting nitrogen conditions.

The glasshouse experiment has proved that $\mathrm{N}$ availability was a major growth factor. At the 2 true leaves stage (day 14 after sowing), the concentration ' $1 / 3 \mathrm{~N}$ ' was not sufficient to allow optimal growth whereas ' $3 \mathrm{~N}$ ' did not permit a 
growth rate much higher than ' $\mathrm{N}$ ' although its total plant $\mathrm{N}$ accumulation was more than two times greater at the swelling fruit stage. These results are consistent with those reported by Widders (1989) for nursery plants. At the beginning of the reproductive phase, ' $1 / 3 \mathrm{~N}$ ' and ' $3 \mathrm{~N}$ ' were inferior in comparison with ' $\mathrm{N}$ ' and so, for a diagnosis, a great accumulation of total dry matter (' $3 \mathrm{~N}$ ') is not necessarily a good indicator of the expected production. Considering truss number and length and fruit DMW, it appeared that $\mathrm{N}$ deficiency (' $1 / 3 \mathrm{~N}$ ' and ' $0 \mathrm{Ns}$ ') resulted in a slower rate of appearance of new trusses. This is in line with the distribution priority for assimilates towards the reproductive organs, particularly swelling fruits (Bonnemain, 1975). On the contrary, $\mathrm{N}$ excess (' $3 \mathrm{~N}$ ') resulted in high shoot growth and new truss differentiation, but in a delayed fruit growth and in high $\mathrm{N}$-concentrations in the plants. In the present range of experimental concentrations, ' $\mathrm{N}$ ' seemed to be an advisable level of nitrogen content in the nutrient solution for young tomato seedlings from emergence till early blooming.

Ethanol extract analysis gave an opportunity to characterize metabolism modifications related to $\mathrm{N}$ availability. High $\mathrm{N}$ availability resulted in chlorophyll synthesis (and green colour) whereas $\mathrm{N}$ shortage resulted in polyphenol synthesis (and yellowish colour). Indeed absorbencies between 300 and $400 \mathrm{~nm}$ are commonly associated with polyphenolic pigments and more precisely between 330 and $340 \mathrm{~nm}$ with compounds derived from cinnamic acid (Monties, 1975). In fact polyphenols are always present in the tomato leaf, particularly chlorogenic acid (Monties, 1975) with an absorption maximum at $334 \mathrm{~nm}$ (Macheix, 1979). They are known to be able to inhibit plant growth regulators (Domenjou and Marigo, 1978) and are thus associated with slower growth (Marigo and Boudet, 1975). They are accumulated in ageing organs. But here their content increased with $\mathrm{N}$ shortage as a consequence of a disturbed protein metabolism. Ethanol extract analysis associated with leaf pigment measurements could be a potentially low-destructive tool for directly diagnosing $\mathrm{N}$ deficiency in young tomato plants (Suniaga Quijada, 1991).

Practically speaking, the management of the nitrogen availability in the field deserves attention. In the present work, plant behaviour in the treatment ' $0 \mathrm{Ns}$ ' was interesting. Under conditions of good water supply, no addition of $\mathrm{N}$ was necessary until the beginning of blooming. Afterwards it became indispensable for avoiding any risk of reducing the production potential. The management of nitrogen fertilization of field tomato crops will be improved when the availability of mineral $\mathrm{N}$ in the soil is better known throughout the crop cycle. In order to reduce the input and the leaching of $\mathrm{N}$ in sown tomato crops, no additional $\mathrm{N}$ will be necessary before the appearance of the first trusses.

\section{References}

Bonnemain J L 1975 Transport et distribution des produits de la photosynthèse. In Photosynthèse et Production Végétale. Ed. C Costes. pp 147-170. Gauthiers-Villars Publishers, Paris, France.

Bourdu R and Gregory N 1983 Etude comparée du début de la croissance chez divers génotypes de maïs. Agron. 3, $761-770$

Champigny M L, Guiraud G, Soualmi-Boujemaa K, Talouizte A and Moyse A 1985 Le rôle des racines et des feuilles dans l'assimilation du nitrate; le cas de la jeune plante de blé. C. R. Acad. Agric. Fr. 71, 283-291.

Cornillon P and Auge M 1980 Cinétique d'absorption des éléments minéraux par la tomate cultivée sous serre, conséquences agronomiques. C. R. Acad. Agric. Fr. 46, $1242-1255$.

Cornilion P and Maisonneuve B 1985 Effets de basses températures appliquées aux parties aérienne ou racinaire de la tomate sur l'absorption d'éléments minéraux et la fertilité pollinique. Agron. 5, 33-38.

Doumenjou N and Marigo G 1978 Relations polyphénolscroissance: rôle de l'acide chlorogénique dans le catabolisme auxinique chez Lycopersicon esculentum. Physiol. Vég. 16, 319-331.

Dumas Y 1990 Interrelation of linear measurements and total leaf area or dry matter production in young tomato plants. Adv. Hortic. Sci, 4, 172-176.

Haag H P, Oliveira G D de, Barbosa V and Silva Neto J M 1978 Nutricao mineral de hortalicas XXXII Marcha de absorcao des nutrientes pelo tomateiro (Lycopersicon esculentum Mill) destinado ao processamiento industrial. An. Esc. Sup. Agric. Luiz de Queiroz 35, 243-269.

Halbrooks M C and Wilcox G E 1980 Tomato Plant Development and Elemental Accumulation. J. Am. Soc. Hortic. Sci. 105, 826-828.

Hoagland D R and Arnon D I 1950 The Water CuIture Method for Growing Plants without Soil. Calif. Agric. Stn. Circ. $347 \mathrm{p}$.

Just D, Saux C, Richard C and Andre M 1989 Effect of 
nitrogen stress on sunflower gas exchange. I. Photorespiration and carbon partitioning. Plant Physiol. Biochem. 27, 669-677.

Macheix J J 1979 Les esters hydroxycinnamiques de la pomme: identification, variations au cours de la croissance du fruit et métabolisme. Thèse, Univ. Paris VI. 167 p.

Marigo G and Boudet A M 1975 Rôle des polyphenols dans la croissance. Définition d'un modèle expérimental chez Lycopersicon esculentum. Physiol. Plant. 34, 51-55.

Monties B 1975 Rayonnement ultraviolet et photosynthése. In Photosynthése et Production Végétale. Ed. C Costes. pp 193-215. Gauthier-Villars Publishers, Paris, France.

Pinto Contreras M 1981 Etude des coûts énergétiques de la croissance de plantules de blé (Triticum aestivum) lors du passage de l'hétérotrophie à l'autotrophie. Thèse INA-PG, Paris. 77 p.

Siband P 1981 Croissance, nutrition et production du mil (Penisetum typhoides). Essai d'analyse du fonctionnement du mil en zône sahélienne. Thèse d'Etat, Univ. de Montpellier. $302 \mathrm{p}$.

Suniaga Quijada J 1991 Nutrition azotée de la tomate de type déterminé, issue de semis. Analyse de la croissance et du développement au stade jeune. Thèse de doctorat, Université de Rennes I. 180 p.

Widders I E 1989 Pretransplant treatments of N and P influence growth and elemental accumulation in tomato seedlings. J. Am. Soc. Hortic. Sci. 114, 416-420. 